\title{
A Study on the Relationship among Coaching Leadership Job Autonomy and Job Commitment
}

\author{
Ju-young Park ${ }^{1}$ and Kuk-hoan Wee ${ }^{2}$ \\ ${ }^{1}$ Dongguk University, Korea \\ ${ }^{2}$ Sungduk University, Korea \\ ${ }^{1}$ wndud718@hanmail.net, ${ }^{2}$ whh64@sdc.ac.kr
}

\begin{abstract}
This study is to empirically investigate the effect of coaching leadership in the education section. This study is to construct the sub-dimensions (direction, development, accountability) of coaching leadership, job autonomy, and job commitment. To achieve the research purpose, we conducted a questionnaire survey of 230 working members of the school in Gyeongnam province and Pusan in Korea, and collected 223 cases, and verified the hypotheses through SPSS and AMOS analysis with final data of 205. As a result, coaching leadership that constructs sub-dimensions of direction, development, and accountability influence job autonomy and job commitment, respectively. Besides, job autonomy significantly influences job commitment. These results suggested that coaching is a new and effective leadership style that influences members of the school's attitude or organization effectiveness. Therefore, it is meant to provide an implication that coaching leadership should be exercised to raise the job autonomy and commitment of employees.
\end{abstract}

Keywords: Coaching leadership, Job autonomy, Job commitment

\section{Introduction}

Rapid changes in the business environment are very demanding of organizational flexibility for all organizations, including school organizations. Organizational leaders, therefore, need to exercise effective leadership to motivate their employees to voluntarily devote themselves to their jobs, rather than to their bosses' top-down approach in the previous vertical structure.

Coaching skills not only meet the needs of members of the organization, are placed on growth and achievement in building the capacity of members. Additionally, coaching, which opens the minds of employees and enables them to work with new ideas and other approaches, enables talent-centered management, contributing to the achievement of goals by improving not only the members but also the organization's growth and performance [1]. This is the basis for securing corporate competitiveness. For these reasons, the importance and contribution of coaching are increasing day by day, and coaching is an important part of the leadership that lies with organizational leaders and executives.

Therefore, today, coaching is used in various organizations such as large corporations, SMEs, government agencies, educational institutions, medical institutions, and charities, and the term of the coach is recognized as the mainstream of society. Besides, leadership in

Article history:

Received (October 12, 2019), Review Result (November 26, 2019), Accepted (January 3, 2020) 
education institutions often gets attention, mostly due to increasing responsibilities for school leaders and the accountability-driven context they work in [2]. For these reasons coaching leadership gets attention from academic and practical areas, especially principals' leadership is the vital factor to influence members' attitudes and behaviour of school the organizational performance. This paper is to investigate the coaching leadership that constructs subdimensions of development, development, and accountability that influences job autonomy and job commitment in school settings.

\section{Literature review}

\subsection{Coaching leadership}

Early academic research on coaching leadership was done by Stowell. He referred to the components of coaching leadership as direction, development, accountability, and relationship feedback [3]. Furthermore, Gerbarg [4] discusses the view that organizations need to learn more about the importance of investment in leadership training. Such as operating managerial leadership programs, coaching leadership programs. He emphasizes investment in coaching as one of the keys to sustainable success, as Gray [5] underlined that coaching is a very essential method for the development of members and performance in organizations. Indeed, coaching is now recognized as a major competence for organizational leadership [6].

Meanwhile, coaching skills that develop careers so that they can perform better in the job are important. Further, it can be seen that the relationship with stakeholders outside the organization is an important key to improving the effectiveness of the organization, in addition to forming friendly relationships among the members of the organization.

In this view, there is a growing interest in coaching leadership in academia and practice areas. Coaching leadership is defined as the process of presenting to those receiving coaches how to perform their jobs, communicating organizational expectations, giving feedback, encouraging them to solve problems, and helping them to realize their potential [7].

Coaching leadership is the application of the basic philosophy of coaching to leadership. It consists of three philosophies of coaching. First, everyone has unlimited possibilities. Second, the solution necessary for the person exists inside the person. Third, a partner is needed to find the answer. This coaching leadership is a flexible way of changing managers' leadership so that managers can exercise coaching leadership while emphasizing a partner-like relationship where managers and employees solve problems together in the flow of change [8].

Meanwhile, several papers proposed that coaching leadership is the effective leadership that improved employee satisfaction [9][10], organizational commitment [11], self-efficacy [12], and organizational performance [13].

Therefore, based on previous studies, this study is to empirically identify the effect of coaching leadership on job autonomy and job commitment.

\subsection{Job autonomy}

Autonomy generally means that professionals have authority in their professional knowledge and status, and autonomous professionals make decisions and act on them. Job autonomy is one of the most important factors for professionals, and the higher the autonomy in a job, the more self-improvement, the better your career, and the more immersive you are in the job [14]. 
Job autonomy is defined as the degree of freedom, independence, and discretion in making important decisions in the job [15]. Job autonomy is one of the job characteristic theories that describe the nature of the job that makes sense, responsibility, and feedback perception of a job [16]. Further, Karasek Jr. [17] proposed that job autonomy is a job characteristic embedded in a member's position in the organization and the surrounding organizational environment. In particular, professional practitioners, such as teachers, educators, expect considerable freedom and discretion in planning their work, determining their work, and choosing how to do it.

According to several pieces of research, the high job autonomy is, the greater intrinsic motivation is [18]. They proposed that the autonomy of teachers was directly related to optimism, teaching commitment, and subjective well-being.

The definitions of job autonomy discussed above include the degree of autonomy, independence, and discretion in their jobs, such as the organizational members can plan their work and choose how to perform their jobs. In this study, job autonomy is defined as the degree of autonomy allowed by the members of the organization to perform their duties and the flexibility provided through their discretion.

\subsection{Job commitment}

Job commitment alludes to the degree to which a member of the organization has a psychological sense of one's work and the importance of his work in self-image [19]. In other words, job commitment is the basis for devoted themselves to the goals set by the organization.

Meanwhile, commitment acts as an antecedent in job satisfaction or organizational commitment. Previous papers have shown that lower job commitment lowers positive sentiment toward the organization and, as a result, increases the likelihood of negatively evaluating exchange relations with the organization [20][21][22]. This suggests that job commitment is an antecedent factor in job satisfaction or organizational commitment.

\section{Methodology}

\subsection{Conceptual model}

This study is to identify the effect of coaching leadership on job autonomy and job commitment. So, the conceptual model of the relationships among sub-dimensions of coaching leadership- direction, development, and accountability on job autonomy and commitment- is presented in [Figure 1] 


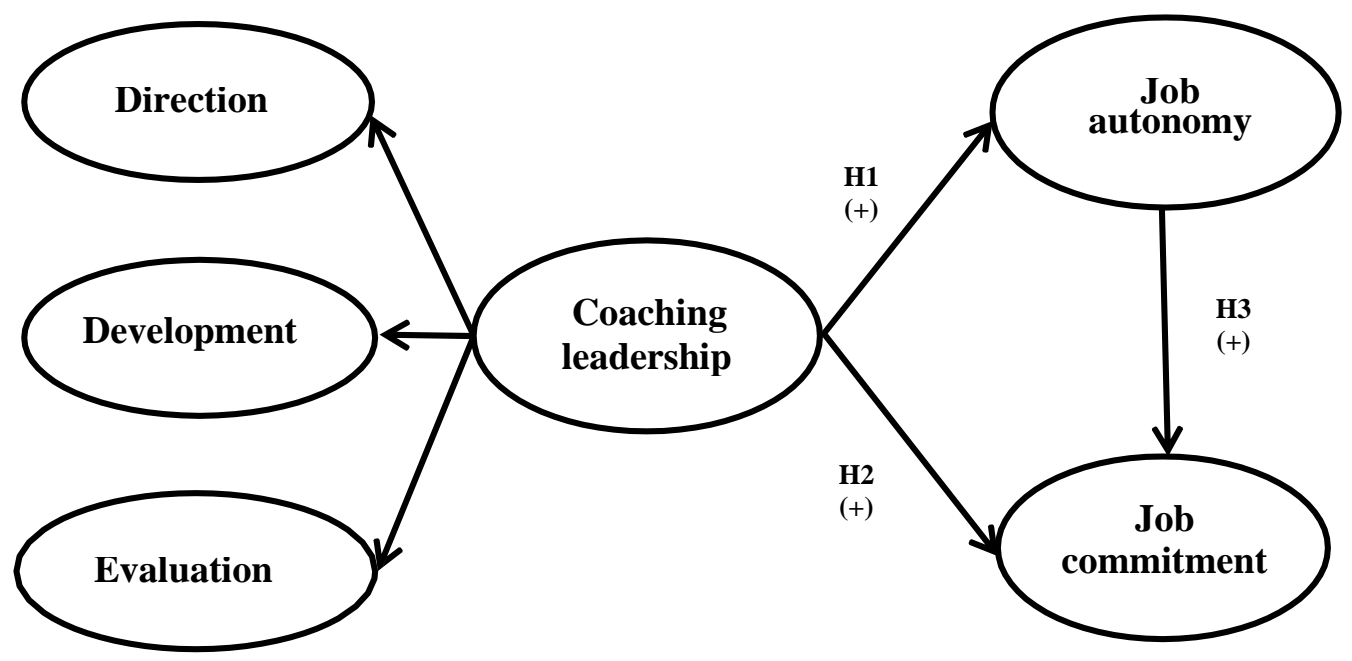

Figure 1. Conceptual model

Based on the previous studies, we set the hypotheses among coaching leadership, job autonomy, and job commitment.

H1: Coaching leadership influence positively job autonomy.

$\mathrm{H} 2$ : Coaching leadership influence positively on job commitment.

H3: Job autonomy influence positively on job commitment.

\subsection{Samples}

A survey was conducted to collect data from schools in Gyeongnam province and Pusan in Korea. When sending out the 230 questionnaires, we get 223 respondents and through the process of data purification, the number of final data for analysis gets 194 valid cases at the end.

\section{Results}

\subsection{Result of confirmatory analysis}

The CFA results are presented in [Table 1]. The reliability (Cronbach's a) of each construct is more than 0.6 , composite reliability of all indicators was above thresholds, which exceeds the acceptable level suggested by Murphy et al. [23] and by Nunnally et al. [24]. So, all factor loadings were statistically significant and reliabilities were above 0.7 . The average variation extracted (AVE) values for all factors were above 0.5 . The results of CFA supported discriminant validity due to all indicators fitted. The CFA model indicated a good fit for data.

AMOS 21.0 was used for the analysis of the measurement model. Goodness of fit was $\chi \chi$ $2 / \mathrm{df}=191.217(100), \mathrm{p}=0.000, \mathrm{CMIN} / \mathrm{DF}=1.912, \mathrm{GFI}=.903, \mathrm{IFI}=.980, \mathrm{TLI}=.973, \mathrm{CFI}=.980$, $\mathrm{RMR}=.068$, RMSEA $=0.067$ as shown in [Table 1]. Cronbach's $\alpha$ value of each variable is 0.926 or more and the CR values are over 0.780 . And the dispersion extraction index was higher than 0.775 . Therefore, reliability and concentration validity were ensured. 
Table 1. Results of confirmatory factor analyses

\begin{tabular}{|c|c|c|c|c|c|c|c|}
\hline Variables & Items & Estimates & SE & $\mathrm{T}$ value & Cronbach' $\alpha$ & $\mathrm{CR}$ & AVE \\
\hline \multirow{3}{*}{ Direction } & $\mathrm{X} 1$ & 0.874 & - & - & \multirow{3}{*}{0.926} & \multirow{3}{*}{0.932} & \multirow{3}{*}{0.820} \\
\hline & $\mathrm{X} 2$ & 0.898 & 0.052 & 18.615 & & & \\
\hline & $\mathrm{X} 3$ & 0.944 & 0.060 & 20.835 & & & \\
\hline \multirow{3}{*}{ Development } & $\mathrm{X} 4$ & 0.948 & 0.038 & 22.202 & \multirow{3}{*}{0.948} & \multirow{3}{*}{0.947} & \multirow{3}{*}{0.857} \\
\hline & $\mathrm{X} 5$ & 0.892 & 0.037 & 27.489 & & & \\
\hline & X6 & 0.936 & - & - & & & \\
\hline \multirow{3}{*}{ Accountability } & $\mathrm{X7}$ & 0.772 & 0.025 & 38.403 & \multirow{3}{*}{0.931} & \multirow{3}{*}{0.936} & \multirow{3}{*}{0.830} \\
\hline & $\mathrm{X} 8$ & 0.969 & 0.046 & 16.498 & & & \\
\hline & $\mathrm{X} 9$ & 0.978 & - & - & & & \\
\hline \multirow{4}{*}{ Job autonomy } & $\mathrm{X} 10$ & 0.969 & - & - & \multirow{4}{*}{0.973} & \multirow{4}{*}{0.978} & \multirow{4}{*}{0.917} \\
\hline & $\mathrm{X} 12$ & 0.947 & 0.036 & 26.505 & & & \\
\hline & $\mathrm{X} 13$ & 0.954 & 0.031 & 32.220 & & & \\
\hline & $\mathrm{X} 14$ & 0.961 & 0.038 & 26.528 & & & \\
\hline \multirow{4}{*}{ Job commitment } & $\mathrm{X} 15$ & 0.752 & 0.046 & 14.085 & \multirow{4}{*}{0.934} & \multirow{4}{*}{0.934} & \multirow{4}{*}{0.780} \\
\hline & $\mathrm{X} 16$ & 0.910 & 0.053 & 21.712 & & & \\
\hline & $\mathrm{X} 17$ & 0.951 & 0.076 & 24.406 & & & \\
\hline & $\mathrm{X} 18$ & 0.907 & - & - & & & \\
\hline \multicolumn{8}{|c|}{$\begin{array}{c}\chi 2 / \mathrm{df}=191.217(100), \mathrm{p}=0.000, \mathrm{CMIN} / \mathrm{DF}=1.912, \mathrm{GFI}=.903, \mathrm{IFI}=.980, \mathrm{TLI}=.973, \mathrm{CFI}=.980, \mathrm{RMR}=.068, \\
\mathrm{RMSEA}=0.067\end{array}$} \\
\hline
\end{tabular}

\subsection{Result of correlations analysis}

[Table 2] showed the results of correlations. The analysis verified discriminant validity, the square root of the AVE of each variable was greater than the correlation coefficients between the variables (off-diagonal elements) [25]. So the discriminant validity of all measurements used can be verified.

Table 2. Results of correlation analysis

\begin{tabular}{|c|c|c|c|c|c|}
\hline & DI & DE & AC & JA & JC \\
\hline Direction & 0.906 & - & - & - & - \\
\hline Development & $0.453^{* *}$ & 0.926 & - & - & - \\
\hline Accountability & $0.157^{*}$ & 0.109 & 0.911 & - & - \\
\hline Job autonomy & $0.206^{* *}$ & $0.244^{* *}$ & $0.219^{* *}$ & 0.958 & - \\
\hline Job commitment & $0.172^{*}$ & $0.218^{* *}$ & 0.070 & 0.021 & 0.883 \\
\hline
\end{tabular}

\subsection{Results of path analysis}

As shown in [Table 3], all hypotheses of $\mathrm{H} 1, \mathrm{H} 2, \mathrm{H} 3$ in the path analysis are supported. Coaching leadership is positively related to job autonomy $(\beta=0.726, p=0.001)$ and job commitment $(\beta=-0.256, p=0.05)$, supporting $\mathrm{H} 1$, and $\mathrm{H} 2$, respectively. Furthermore, job autonomy has a significantly positive effect on job commitment $(\beta=-0.471, p=0.001)$. The results of the path analyses are below. 
Table 3. Results of the path analyses

\begin{tabular}{|c|c|c|c|c|c|c|}
\hline Hypothesis & Path & Estimates & SE & T-value & p-value & Results \\
\hline $\mathrm{H} 1$ & $\begin{array}{c}\text { Coaching leadership } \\
\rightarrow \text { Job autonomy }\end{array}$ & 0.726 & 0.096 & $11.558 * * *$ & $* * *$ & Supported \\
\hline $\mathrm{H} 2$ & $\begin{array}{l}\text { Coaching leadership } \\
\rightarrow \text { Job commitment }\end{array}$ & 0.256 & 0.123 & $3.150 * *$ & $* *$ & Supported \\
\hline $\mathrm{H} 3$ & $\begin{array}{l}\text { Job autonomy } \\
\rightarrow \text { Job commitment }\end{array}$ & 0.471 & 0.079 & $5.893 * * *$ & $* * *$ & Supported \\
\hline$\chi 72 / \mathrm{df}=258.904(119), \mathrm{p}=0.000, \mathrm{CMIN} / \mathrm{DF}=2.176, \mathrm{GFI}=.882, \mathrm{IFI}=.973, \mathrm{TLI}=.964, \mathrm{CFI}=.972, \mathrm{RMR}=.067$, \\
$\mathrm{7}$
\end{tabular}

Significant value at $* * p=0.05,{ }^{* * *} p=0.001$

\section{Conclusions}

This paper investigated the relationship between the coaching leadership that constructs three sub-dimensions (direction, development, and accountability), job autonomy, and job commitment. The results showed that coaching leadership is positively linked with job autonomy and job commitment. Moreover, job autonomy positively influences job commitment.

Consequently, we proved that coaching leadership is an important factor to affect job autonomy of members and organization effectiveness. This study showed that the direction element, development, and accountability of a principal influence the teachers' job attitude in schools. Therefore, principals' coaching leadership is expected to enhance teacher autonomy and organizational commitment and consequently improve organizationally. Especially, principals should enhance organizational performance by providing clear directions, developing career coaching skills, and developing coaching skills through fair evaluation to increase the autonomy of teachers. Moreover, this study showed that the principal, the leader of school organization, must realize the potential of the members of the organization, and then help them develop and use their competence, and create friendly relationships based on trust with the members of the organization to create organizational performance through employee job satisfaction.

In the vein of coaching leadership effectiveness, this study is meant to provide an implication that coaching leadership should be exercised to raise the job autonomy and commitment of employees.

\section{References}

[1] S, -J. Kim, "The relationship between coaching leadership and organizational effectiveness - focusing on mediating effects of individuality, relatedness and job autonomy," M.S. thesis, Korea University of Technology and Education, (2015)

[2] D. H. Hitt and P. D. Tucker, "Systematic review of key leader practices found to influence student achievement: A unified framework," Review of Educational Research vol.86, no.2, pp.531-569, (2016) DOI: 10.3102/0034654315614911

[3] T. Stowell, "Null antecedents and proper government," In Proceedings of NELS," vol.16, pp.476-493

[4] Z. Gerbarg, "Physician leaders of medical groups face increasing challenges," The Journal of Ambulatory Care Management, vol.25, no.4, pp.1-6, (2002) DOI: 10.1097/00004479-200210000-00003 
[5] D. E. Gray, "Executive coaching: Towards a dynamic alliance of psychotherapy and transformative learning processes," Management Learning, vol.37, no.4, pp.475-497, (2006) DOI: 10.1177/1350507606070221

[6] S. Henochowicz and D. Hetherington, "Leadership coaching in health care," Leadership and Organization Development Journal, vol.27, no.3, pp.183-189, (2006) DOI: 10.1108/01437730610657703

[7] L. A. Boyce, R. J. Jackson, and L. J. Neal, "Building successful leadership coaching relationships: Examining the impact of matching criteria in a leadership coaching program," Journal of Management Development, vol.29, no.10, pp.914-931, (2010) DOI: 10.1108/02621711011084231

[8] G. P. Latham, J. Almost, S. Mann, and C. Moore, "New developments in performance management," Organizational Dynamics, vol.34, no.1, pp.77-87, (2005) DOI: 10.1016/j.orgdyn.2004.11.001

[9] S. -J. Kim, "The relationship between coaching leadership and organizational effectiveness, focusing on mediating effects of individuality, relatedness, and job autonomy," Ph.D. Dissertation, Korea University of Technology and Education, (2015)

[10] A. D. Ellinger, A. E. Ellinger, and S. B. Keller, "Supervisory coaching behavior, employee satisfaction, and warehouse employee performance: A dyadic perspective in the distribution industry," Human resource development quarterly, vol.14, no.4, pp.435-458, (2003) DOI: 10.1002/hrdq.1078

[11] K. H. Lee and Y. J. Lee, "Effects of coaching leadership and moderating effects of trust in leader and followership on job satisfaction among dental hygienists," The Korean Journal of Health Service Management, vol.10, no.1, pp.79-91, (2016)

[12] S. -H. Park, "An examination of the impact of managerial coaching behaviors on employees, learning, organizational commitment, and turnover intentions," Journal of Vocational Education and Training, vol.13, no.3, pp.75-99, (2010)

[13] E. de Haan, A. Duckworth, D. Birch, and C. Jones, "Executive coaching outcome research: The contribution of common factors such as relationship, personality match, and self-efficacy," Consulting Psychology Journal: Practice and Research, vol.65, no.1, pp.40, (2013) DOI: 10.1037/a0031635

[14] K. C. Kwon and H. S. Yang, "Structural relationships between the variables of coaching leadership, job characteristics and organizational effectiveness in convergence environment." Journal of Digital Convergence, vol.14, no.5, pp.247-262, (2016)

[15] D. P. Moynihan and S. K. Pandey, "Finding workable levers over work motivation: Comparing job satisfaction, job involvement, and organizational commitment," Administration and Society, vol.39, no.7, pp.803-832, (2007) DOI: 10.1177/0095399707305546

[16] J. R. Hackman and G. R. Oldham, "Development of the job diagnostic survey," Journal of Applied psychology, vol.60, no.2, pp.159

[17] R. A. Karasek Jr., "Job demands, job decision latitude, and mental strain: Implications for job redesign," Administrative science quarterly, pp.285-308

[18] N. W. Van Yperen and M. Hagedoorn, "Do high job demands increase intrinsic motivation or fatigue or both? The role of job control and job social support," Academy of Management Journal, vol.46, no.3, pp.339-348, (2003) DOI: 10.5465/30040627

[19] R. W. Rice, M. A. Bonacci, and B. B. Bunker, "Involvement with the prior job, social support, and the perceived quality of life among the unemployed," State University of New York at Buffalo Dept of Psychology

[20] J. E. Mathieu and J. L. Farr, "Further evidence for the discriminant validity of measures of organizational commitment, job involvement, and job satisfaction,” Journal of Applied Psychology, vol.76, no.1, pp.127

[21] F. P. Morgeson and S. E. Humphrey, "The work design questionnaire (WDQ): Developing and validating a comprehensive measure for assessing job design and the nature of work," Journal of applied psychology, vol.91, no.6, pp.13-21, (2006) DOI: 10.1037/0021-9010.91.6.1321

[22] A. Hermawati and N. Mas, "Mediation effect of quality of work-life, job involvement, and organizational citizenship behavior in the relationship between transglobal leadership to employee performance," 
International Journal of Law and Management, vol.59, no.6, pp.1143-1158, (2017) DOI: 10.1108/IJLMA-082016-0070

[23] K. R. Murphy and C. O. Davidshofer, "Psychological testing," Principles and Applications, Englewood Cliffs [24] J. C. Nunnally and I. H. Bernstein, "Psychometric theory (3rd ed.)," New York: McGraw-Hill

[25] C. Fornell and D. F. Larcker, "Structural equation models with unobservable variables and measurement error: Algebra and statistics," SAGE Publications Sage CA: Los Angeles, CA

\section{Authors}

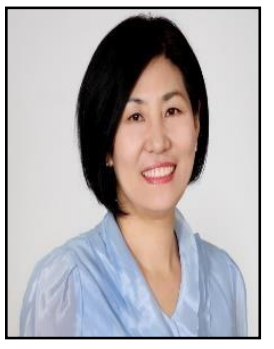

\section{Ju-young Park}

Professor of the Department of Social Welfare at Dongguk University, South Korea

Ph.D. in the Department of Social Welfare from Dongguk University, South Korea

Her current research interests include welfare management and leadership. Published papers in well-known Korean journals such as Koran Academy of Social Welfare and international journals of SCOPUS.

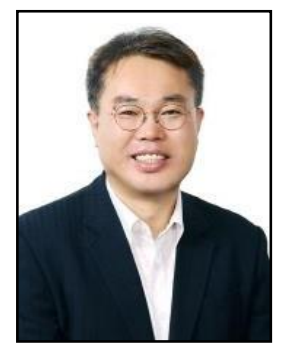

\section{K uk-hoan Wee}

Professor of Department of Convergence Wellness at Sungduk University, South Korea

Ph.D. in the Department of Law School from Donga University, South Korea

Ph.D. Courses in Marin Convergence Design, Pukyong National University, South Korea

Doctor of Christian Counseling-Coaching completion. His current research interests include safety management and leadership. Published papers in well-known Korean journals such as Koran Academy of Social Welfare and international journals of SCOPUS. 